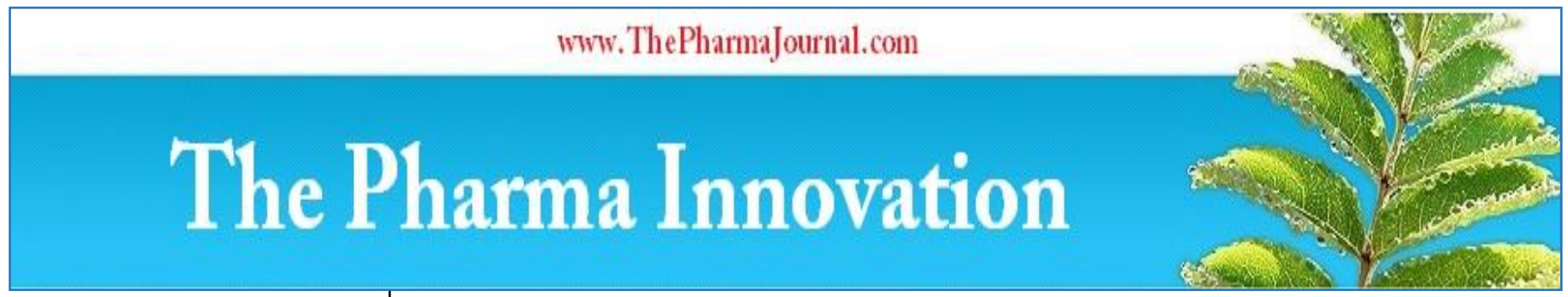

ISSN (E): 2277 - 7695

ISSN (P): 2349-8242

NAAS Rating: 5.23

TPI 2022; 11(3): 168-171

(C) 2022 TPI

www.thepharmajournal.com

Received: 02-01-2022

Accepted: 11-02-2022

\section{Kavitha R}

Department of Fruit Science, K.R.C.C.H, Arabhavi, UHS

Bagalkot, Karnataka, India

\section{Nataraja KH}

Assistant Professor, Department of Fruit Science, K.R.C.C.H Arabhavi, UHS Bagalkot,

Karnataka, India

Nagesh $\mathbf{N}$

Professor and Head, Department of Fruit Science, K.R.C.C.H Arabhavi, UHS Bagalkot, Karnataka, India

\section{Mahanthesha BN Naika}

Assistant Professor, Department

of Biotechnology and Crop

Improvement, K.R.C.C.H

Arabhavi, UHS Bagalkot,

Karnataka, India

\section{Kantharaju V}

Associate Professor, Department of Plant Pathology and Head, AICRP (Fruits), K.R.C.C.H, Arabhavi, UHS Bagalkot,

Karnataka, India

\section{Corresponding Author:}

Kavitha R

Department of Fruit Science

K.R.C.C.H, Arabhavi, UHS

Bagalkot, Karnataka, India

\section{Performance of different mango (Mangifera indica $\mathbf{L}$.) varieties for flowering and fruiting attributes under high density planting}

\author{
Kavitha R, Nataraja KH, Nagesh N, Mahanthesha BN Naika and Kantharaju V
}

DOI: https://doi.org/10.22271/tpi.2022.v11.i3c.11162

\begin{abstract}
An experiment was conducted to study the performance of different mango varieties for flowering and fruiting attributes under high density planting. Among the varieties evaluated wide variations were observed, with respect to flowering characteristics variety Kesar recorded maximum number of panicles (79.79) and panicle length $(40.22 \mathrm{~cm})$ whereas, minimum number of panicles per plant and panicle length was recorded in Amrapali (52.48 and $34.13 \mathrm{~cm}$ respectively). The variety Totapuri recorded maximum panicle width $(28.17 \mathrm{~cm})$, number of hermaphrodite flowers per panicle $(260.34)$. whereas, minimum panicle width (23.00) was recorded in Alphonso and no. of hermaphrodite flowers/panicle was in Kesar (116.78). In case of fruiting characteristics maximum fruit set percent was recorded in Totapuri $(6.80 \%)$ while minimum was in Kesar (5.17). The number of fruits per plant was highest in (48.10) and minimum was in (31.15) fruit yield was recorded highest in Mallika (10.15 kg/plant) and lowest in Amrapali (4.97 $\mathrm{kg} / \mathrm{plant}$ ). Out of five varieties evaluated Mallika has produced desirable fruits with high yield which makes it suitable for high density planting system.
\end{abstract}

Keywords: Mango, high density planting system, Mallika, flowering, fruiting

\section{Introduction}

Mango (Mangifera indica L.) is one of the India's most important fruit crop and it belongs to Anacardiaceae family, which includes 75 genera and 700 species (Lizada, 1993) ${ }^{[12]}$. The origin and the center of diversity of this genus is mainly Southeast Asia. It is the most important species of this genus and is currently grown throughout the tropical regions of the world. Internationally it is recognized as the ambassador fruit of India and because of delicious taste, excellent flavor, attractive fragrance, religious and medicinal importance of the plant it is considered to be the "King of fruits" and "National Fruit of India". It is also rich in vitamin A and C. The High density planting (HDP) system is an intensive system of fruit production that is extremely important for the food and nutritional security of the world's growing population. It is one of the most cutting-edge ideas for increasing productivity without compromising fruit quality. Fruit crops such as mango (Santharam, 1993) ${ }^{[14]}$, banana (Sathiamoorthy and Mustaffa, 2001) ${ }^{[15]}$ and citrus (Goswami et al., 1993) ${ }^{[3]}$ have been successfully implicated in this planting system since it results in grater exploitation of natural resources. HDP gives earlier production, improved return per unit area, easy harvesting, eco-friendly and allows for effective use of land, resources such as light, water and fertilizers, as well as efficient pesticides application. Plant response to planting density is influenced by internal plant characteristics such as rootstock, canopy age, vigour and extrinsic factors such as soil and climate (Yamakura et al., 2008) ${ }^{[17]}$. One of the prerequisites for effective mango production is the evaluation of mango varieties for specific conditions under high density planting system. This research will aid in identifying the suitability of variety for growing under HDP system among the different mango varieties under study.

\section{Materials and Methods}

The experiment was undertaken at Kittur Rani Channamma College of Horticulture, Arabhavi (Belagavi), University of Horticultural Sciences, Bagalkot (Karnataka), India during June 2017 to May - 2018 to evaluate the performance of different mango varieties for fruit physical and yield parameters under high density planting. Arabhavi is situated in Northern dry tract of Karnataka state at $16^{\circ} 15^{\prime}$ North latitude and $74^{\circ} 45^{\prime}$ East longitude and at an altitude of 612.03 $\mathrm{m}$ above the mean sea level. 
The orchard was established during 2013 and the grafted mango varieties viz., Alphonso $\left(\mathrm{T}_{1}\right)$, Amrapali $\left(\mathrm{T}_{2}\right)$, Kesar $\left(\mathrm{T}_{3}\right)$, Mallika $\left(\mathrm{T}_{4}\right)$ and Totapuri $\left(\mathrm{T}_{5}\right)$ were planted at $3.0 \mathrm{~m} \times$ $2.0 \mathrm{~m}$ spacing in black deep soil with drip irrigation. The experiment was laid out in Randomized Block Design (RBD) with six replications. The observations were recorded on flowering characteristics viz., total number of panicles per plant at completion of flowering, length of panicle $(\mathrm{cm})$, width of panicle $(\mathrm{cm})$ and number of hermaphrodite flowers/panicle which was counted physically at full bloom stage. Fruiting characters like fruit set percentage was calculated by dividing number of fruit set at pea stage per panicle to number of hermaphrodite flower per and expressed in percentage.

$$
\text { Fruit set } \%=\frac{\text { Number of fruit set at pea stage }}{\text { Number of hermaphrodite flowers }} \times 100
$$

The total number of fruits per plant was recorded at the time of harvesting and the data was subjected to statistical analysis.

\section{Results and Discussion Flowering attributes}

The data pertaining to flowering attributes were statistically significant among the varieties and are presented in Table 1.

\section{Total number of panicles per plant}

The total number of panicles per plant was found statistically significant among the treatments. It was observed that the total number of panicles per plant at completion of flowering the were recorded maximum in Kesar (79.79) followed by Alphonso (74.57) and Mallika (71.53) which are on par with each other. The minimum number of panicles per plant was recorded in Amrapali (52.48). which is in conformity with the findings of Gujante et al. (2004) and Kalambe et al. (2009) ${ }^{[7]}$. The variation in the total number of panicle might be due to response of trait to environmental condition.

\section{Size of panicle}

From the experiment it was evident that there were variations in the panicle size of different mango varieties under high density planting system (figure 1). The variety Kesar produced maximum length of panicle Kesar $(40.22 \mathrm{~cm})$ followed by Totapuri $(36.55 \mathrm{~cm})$. Whereas, Amrapali (34.13 $\mathrm{cm})$ produced minimum panicle length and this result was in accordance with the findings of Hada and Singh (2017) ${ }^{[5]}$. The width of panicle was recorded maximum in Totapuri $(28.17 \mathrm{~cm})$ followed by Mallika $(25.20 \mathrm{~cm})$ and the minimum breadth of panicle was recorded in Alphonso $(23.00 \mathrm{~cm})$. The variation in panicle length and width might be due to activity of GA-like substance during floral bud induction and response of trait to environmental condition. Kumar and Jaiswal (2004) ${ }^{[9]}$ stated that the possible cause of difference in panicle length and width may be due to environmental conditions. The results were in accordance with the findings of Majumder $e t$ al. (2011) ${ }^{[13]}$ and Kundu et al. (2009) ${ }^{[9]}$.

\section{Number of hermaphrodite flowers/panicle.}

It was clearly observed that there was significant difference in number of hermaphrodite flowers per panicle. The maximum number of hermaphrodite flowers/panicle was recorded in
Totapuri (260.34) followed by Amrapali (212.28) whereas, the minimum number of hermaphrodite flowers per panicle was recorded in Kesar (116.78). Similar finding had also reported by Kalambe et al. (2009) ${ }^{[7]}$. According to Hada and Singh (2017) ${ }^{[5]}$ the variation in the number of hermaphrodite flowers per panicle attributed to inherent genetic differences of the mango cultivars.

\section{Fruiting attributes}

The data pertaining to fruiting attributes were statistically significant among the varieties and are presented in Table 2.

\section{Per cent fruit set per panicle}

The per cent fruit set per panicle was recorded maximum in Totapuri (6.80\%) which was on par with Amrapali (6.27\%) and Mallika (5.66\%). Totapuri recorded highest fruit set $\%$ because this variety had maximum number of hermaphrodite flowers per panicle. The findings are in accordance with the findings of Jatav (2014) ${ }^{[6]}$. The minimum number of fruit set per cent at pea stage was recorded in Kesar $(5.17 \%)$ because it had the minimum number of hermaphrodite flowers per panicle. The variation in the fruit set per cent is a varietal character that depends on the several factors such as time of flowering, sex ratio, efficient cross pollination and intensity of flower and fruit drop.

\section{Number of fruits per plant}

Number of fruits per tree and high yield is a very important desirable character to be considered in any varietal evaluation. The variation in the yield of fruits in different cultivars might be due to the inherent variation in the absorption and translocation of photosynthates and plant hormones, fruit set, fruit retention, tree size and leaf area of an individual variety. Significantly maximum number of fruits per plant was harvested in Kesar (48.10) followed by Amrapali (40.05). Similar results were obtained by Gujante et al. (2009) ${ }^{[4]}$. The minimum number of fruits per plant was harvested in Mallika (26.29). The result was in accordance with the findings of Singh et al. (2014) ${ }^{[16]}$. Higher number of fruit per plant may be due to enhanced number of panicles per branch, higher net photosynthetic rate.

\section{Fruit yield/plant}

The fruit yield on weight basis per plant was recorded maximum in Mallika (10.15 kg/plant) and it is due to less number of fruits per plant increased the size and is also due to genetic makeup of the plant. The result was in line with the findings of Singh et al. (2014) ${ }^{[16]}$, Dangi et al. (2017) ${ }^{[2],}$ Chanana et al. (2005) ${ }^{[1]}$, Kumar and Singh (2005) ${ }^{[10]}$ and Kumar (2003) ${ }^{[8]}$. The minimum fruit yield per plant was recorded in Amrapali (4.97 kg/plant). This result corroborated with the findings of Dangi et al. (2017) ${ }^{[2]}$. The variation among the varieties may be due to varietal differences. The findings of the study are supported by the idea that yield is highly variable factor depending upon the cultivar, climatic conditions, incidence of pest and diseases. Majority of the workers quoted that the yield potential was varietal character. The increase in the yield in terms of weight might be either due to large sized fruits or due to number of fruits per plant (Hada and Singh, 2017) ${ }^{[5]}$. 
Table 1: Flowering characteristics of different mango varieties under high density planting.

\begin{tabular}{|c|c|c|c|c|}
\hline Treatments & $\begin{array}{c}\text { Total number of } \\
\text { panicles/plant }\end{array}$ & $\begin{array}{c}\text { Length of } \\
\text { panicle }(\mathbf{c m})\end{array}$ & $\begin{array}{c}\text { Width of panicle } \\
\text { (cm) }\end{array}$ & $\begin{array}{c}\text { No of hermaphrodite } \\
\text { flowers/panicle }\end{array}$ \\
\hline $\mathrm{T}_{1}-$ Alphonso & 74.57 & 34.73 & 23.00 & 137.26 \\
\hline $\mathrm{T}_{2}-$ Amrapali & 52.48 & 34.13 & 24.89 & 212.28 \\
\hline $\mathrm{T}_{3}-$ Kesar & 79.79 & 40.22 & 23.22 & 116.78 \\
\hline $\mathrm{T}_{4}-$ Mallika & 71.53 & 35.02 & 25.20 & 208.91 \\
\hline $\mathrm{T}_{5}$ - Totapuri & 56.25 & 36.55 & 28.17 & 14.73 \\
\hline S.Em \pm & 6.88 & 0.86 & 0.73 & 43.45 \\
\hline CD @ 5\% & 20.29 & 2.55 & 2.16 & \\
\hline
\end{tabular}

Table 2: Fruiting characteristics of different mango varieties under high density planting system

\begin{tabular}{|c|c|c|c|}
\hline Treatments & Fruit set $(\%)$ & No of fruits/plant & Fruit yield (kg/plant) \\
\hline $\mathrm{T}_{1}-$ Alphonso & 5.27 & 33.07 & 6.55 \\
\hline $\mathrm{T}_{2}-$ Amrapali & 6.27 & 40.05 & 4.97 \\
\hline $\mathrm{T}_{3}-$ Kesar & 5.17 & 48.10 & 9.04 \\
\hline $\mathrm{T}_{4}-$ Mallika & 5.66 & 26.29 & 10.15 \\
\hline $\mathrm{T}_{5}-$ Totapuri & 6.80 & 31.15 & 8.35 \\
\hline S.Em \pm & 0.40 & 2.10 & 0.51 \\
\hline CD @ 5\% & 1.20 & 6.20 & 1.50 \\
\hline
\end{tabular}
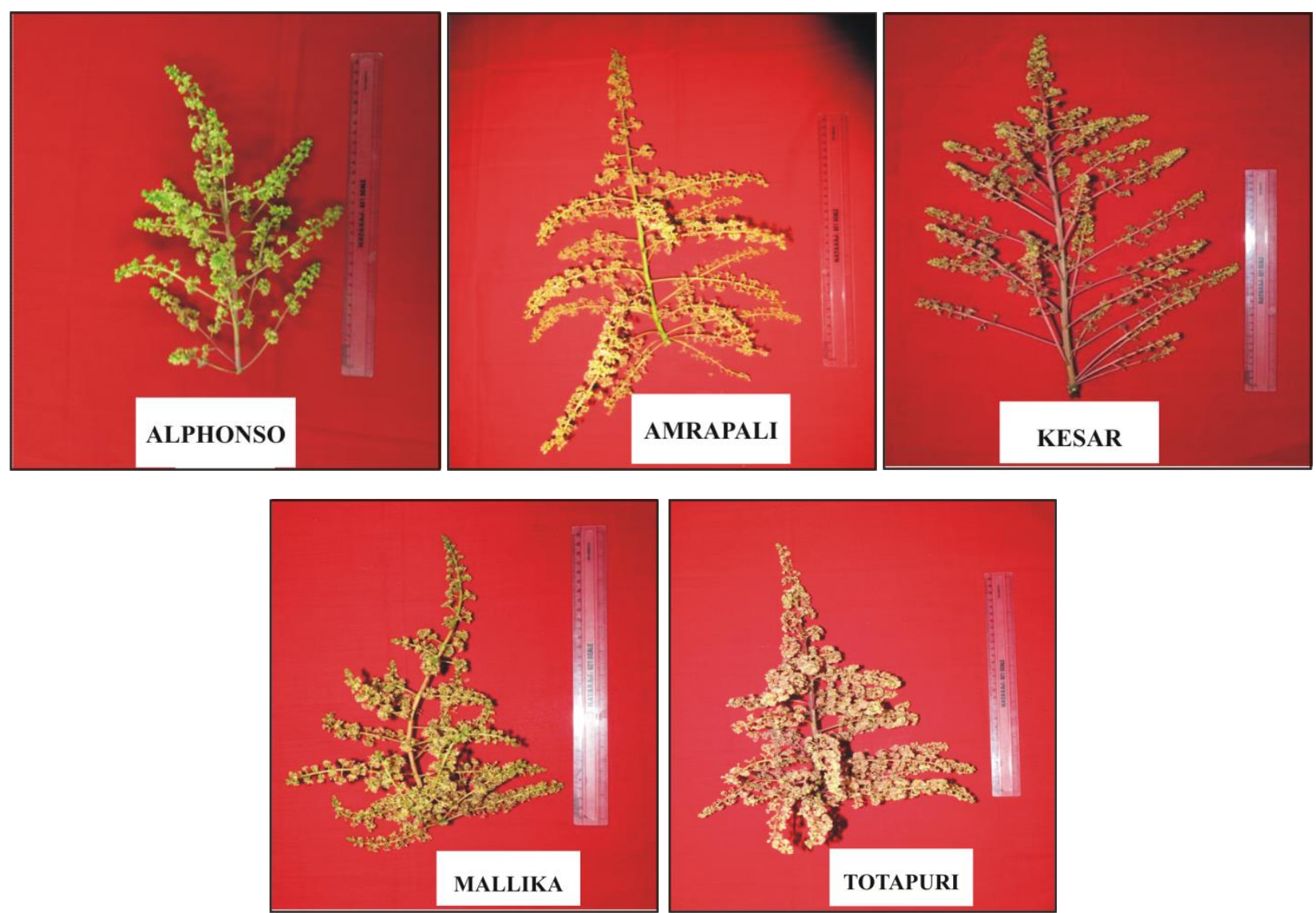

Fig 1: Inflorescence of different mango varieties under high density planting system

\section{Conclusion}

Based on the findings of the present study it can be deduced that, among the different varieties evaluated Mallika has semi vigorous growth along with the good reproductive and fruiting characters under present set of environmental conditions. Hence, Mallika is suitable for growing under high density planting system.

\section{Reference}

1. Chanana YR, Josan JS, Arora PK. Evaluation of some mango cultivars under North Indian conditions. In: International conference on Mango and Date Palm:
Culture and Export, held at University of Agriculture, Faisalabad. 2005, 34-38.

2. Dangi KK, Singh AK, Varan R, Jain VK. Characterization of different mango cultivars for fruit set and yield. Indian J. Eco. 2017;44(6):751-754.

3. Goswami AM, Saxena SR, Kurein. High density planting in citrus, Advances in Hort. 1993;2:645-648.

4. Gunjate RT, Kumbhar AR, Thimaiah IM, Amin SM. Growth and fruiting of some mango cultivars under high density plantation in arid conditions of Gujarat (India) Acta Hortic. 2009;820:403-406.

5. Hada TS, Singh AK. Evaluation of Mango (Mangifera 
indica L.) cultivars for flowering, fruiting and yield attributes. Int. J. Bio-resource Stress Mang. 2017;8(4):505-509.

6. Jatav A. Evaluation and correlation studies in mango genotypes under Kymore plateau of Madhya Pradesh, M.Sc. Thesis, Jawahar Neharu Krishi Vishwavidhyalaya, Jabalpur (M.P). 2014.

7. Kalambe NV. Studies on flowering and fruiting behaviour of mango (Mangifera indica L.) in Chhattisgarh plains. M. Sc.(Ag) Thesis. Indira Gandhi Krishi Vishwavidyalaya, Raipur. 2009.

8. Kumar A. Studies on phenotypic and physico-chemical characteristics on mango hybrids (Mangifera indica L.). Ph.D Thesis, Birsa Agricultural University, Ranchi (Jharkhand). 2003.

9. Kumar N, Jaiswal US. Bearing behaviour of some South and West India mangoes and its vegetative growth. Haryana J. Hort. Sci. 2004;33(1, 2):9-10.

10. Kumar R, Singh S. Evaluation of mango genotypes for flowering, fruiting and fruit quality attributes. Orissa $\mathrm{J}$. Hort. 2005;33(1):77-79.

11. Kundu S, Sanyal N, Datta P. Studies on potentiality of some mango varieties in West Bengal. J. Crop Weed, 2009;5(2):68-71.

12. Lizada C. In: Mango, Seymour, G. B., Taylor, J. E. and Tucker, G. A. (eds). Biochemistry of fruit ripening. Chapman and Hall, London. 1993, 255-271.

13. Majumder DAN, Hassan L, Rahim MA, Kabir MA. Studies on physiomorphology, floral biology and fruit characteristics of mango. J. Bangladesh Agril. Univ. 2011;9(2):187-199.

14. Santharam. High density planting in mango. Advances in Horticulture, Fruit Crops. 1993;I:641-644.

15. Sathiamoorty S, Mustaffa MM. High density planting system in banana planting - An overview. South Indian Horticulture. 2001;49(special):6-12.

16. Singh D. Pheno-physiological and bioactive attributes of commercial Indian mango cultivars. M.Sc. Thesis, Bihar agricultural university, Sabour (India). 2014.

17. Yamakura T, Hosomi A, Hirayama D. Effect of tree spacing on vegetative growth and reproduction in an early growth stage in two cultivars of fig (Ficus carica L.). J. Japanese Soc. for Hort. Sci. 2008;77:7-16. 